Volume 5

June 2019

\title{
The Community Relations Service's Work in Preventing and Responding to Unfounded Racially and Religiously Motivated Violence after $9 / 11$
}

Grande Lum

grande.lum@menlo.edu

Follow this and additional works at: https://scholarship.law.tamu.edu/journal-of-property-law

Part of the Disaster Law Commons

\section{Recommended Citation}

Grande Lum, The Community Relations Service's Work in Preventing and Responding to Unfounded Racially and Religiously Motivated Violence after 9/11, 5 Tex. A\&M J. Prop. L. 139 (2018).

Available at: https://doi.org/10.37419/JPL.V5.12.2 


\title{
The Community Relations Service's Work in Preventing and Responding to Unfounded Racially and Religiously Motivated VIOLENCE AFTER 9/11
}

\author{
By: Grande Lum $\dagger$
}

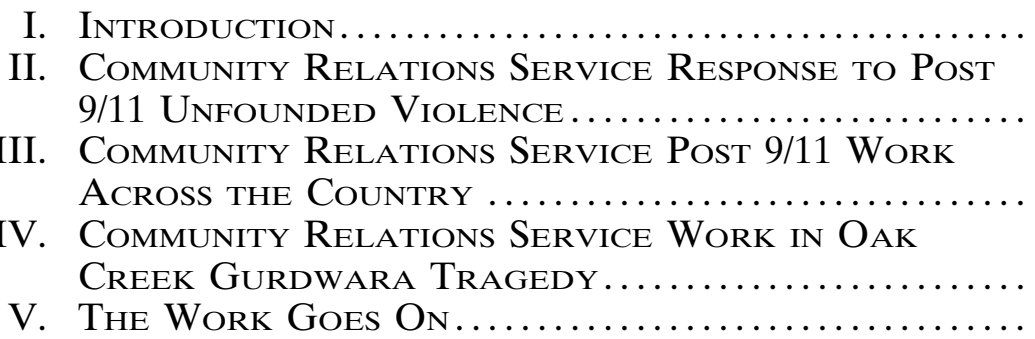

\section{INTRODUCTION}

On the morning of September 11, 2001, New York City-based Community Relations Service ("CRS") Regional Director Reinaldo Rivera was at a New Jersey summit on racial profiling. ${ }^{2}$ At 8:46 a.m., an

1. A version of this article will appear as a chapter in the forthcoming Resolving Racial Conflict: The Community Relations Service and Civil Rights, 1964-2016. 2nd edition. Thanks to Nancy Rogers, Janet Martinez, Nancy Welsh, Bill Froehlich, and Josh Stulberg for their support of this article. Additional appreciation to Elisabeth Andrews for her research and editing assistance. I am also profoundly grateful to the employees of the Community Relations Service for the work they do, often without publicity or credit.

$\dagger$ Community Project and Distinguished Practitioner in Residence at the Ohio State University Moritz College of Law. Grande Lum was nominated by President Barack Obama and confirmed by the Senate in 2012 as the Director of the Community Relations Service (CRS), an agency within the Department of Justice. Before joining CRS, Grande Lum was a clinical professor at the University of California Hastings School of the Law, where he directed the Center for Negotiation and Dispute Resolution. Mr. Lum previously founded the training firm Accordence, where he remains Senior Advisor. He was also Director of the Historically Underutilized Business Zone Program in the United States Small Business Administration. He authored The Negotiation Fieldbook and Tear Down the Wall: Be Your Own Mediator in Conflict. Grande Lum received his B.A. from the University of California at Berkeley, and his J.D. from Harvard Law School.

2. The Community Relations Service is an agency within the United States Department of Justice created by the 1964 Civil Rights Act Title X. Per Section 1002 "It shall be the function of the (Community Relations) Service to provide assistance to communities and persons therein in resolving disputes, disagreements, or difficulties relating to discriminatory practices based on race, color, or national origin which impair the rights of persons in such communities under the Constitution or laws of the United States or which affect or may affect interstate commerce. The Service may offer its services in cases of such disputes, disagreements, or difficulties whenever, in its judgment, peaceful relations among the citizens of the community involved are threatened thereby, and it may offer its services either upon its own motion or upon the request of an appropriate State or local official or other interested person. For

DOI: https://doi.org/10.37419/JPL.V5.I2.2 
American Airlines 767 crashed into the North Tower of New York City's World Trade Center. ${ }^{3}$ Because Rivera was with the New Jersey state attorney general, he quickly learned of the attack. Rivera immediately called his staff members, who at that moment were traveling to Long Island, New York, for an unrelated case. Getting into Manhattan had already become difficult, so Rivera instructed his conciliators to remain on standby. At 9:03 a.m., another 767, United Airlines Flight 175, flew into the World Trade Center's South Tower. ${ }^{4}$

September 11 initiated a new, fraught-filled era for the United States. For CRS, an agency within the United States Department of Justice, it was the beginning of a long-term immersion into conflict issues that involved discrimination and violence against those whose appearance led them to be targets of anti-terrorist hysteria or misplaced backlash. Appropriately, in the days following 9/11, the federal government, including the Federal Bureau of Investigation ("FBI"), concentrated on ferreting out the culprits of the heinous acts. However, the FBI discovered that Middle Eastern terrorists were responsible for the tragedies, and communities around the nation saw a surge of violence against people who appeared to be of Middle Eastern descent, requiring a response to protect those who were unfairly targeted. ${ }^{5}$

These outbreaks began as soon as September 12. Police in Illinois stopped 300 people from marching on a Chicago-area mosque. ${ }^{6}$ In Gary, Indiana, a masked gunman shot twenty-one times at a YemeniAmerican gas station attendant. ${ }^{7}$ In Texas, a mosque was hit by six

additional background on CRS, see Community Relations Service, U.S. Dep't Just., https://www.justice.gov/crs [https://perma.cc/KSM4-67XL] (last visited Feb. 12, 2019). See also Jeff Linkous, NJ Kicks Off Summit on Racial Profiling, Trentonian (Sept. 11, 2001), https://www.trentonian.com/news/nj-kicks-off-summit-on-racial-profiling/ar ticle_2ea9eee3-492b-5e78-9a43-b3608e5745fc.html [https://perma.cc/D85B-QNXN]; Reinaldo Rivera Jr., http://www.national-consortium.org/ /media/Microsites/Files/Na tional\%20Consortium/ Conferences/2015/Bios/Reinaldo\%20Rivera\%20Jr\%20bio .ashx [https://perma.cc/GC9R-MA3J] (last visited Oct. 10, 2018).

3. 9/11 Timeline, History, https://www.history.com/topics/21st-century/9-11-time line [https://perma.cc/M2RP-EJLC] (last updated Sept. 11, 2018).

4. Id.

5. Aliyah Frumin \& Amanda Sakuma, Hope and Despair: Being Muslim in America After 9/11, NBC News (Sept. 11, 2016, 9:07 AM), https://www.nbcnews.com/ storyline/9-11-anniversary/hope-despair-being-muslim-america-after-9-11-n645451

[https://perma.cc/2Y7E-ZWVD]. See also Lena Kampf \& Indra Sen, History Does Not Repeat Itself, But Ignorance Does: Post-9/11 Treatment of Muslims and the LibertySecurity Dilemma, Humanity in Action, https://www.humanityinaction.org/knowl edgebase/168-history-does-not-repeat-itself-but-ignorance-does-post-9-11-treatmentof-muslims-and-the-liberty-security-dilemma [https://perma.cc/4B6B-HFNP] (last visited Oct. 10, 2018).

6. Chris Wragge, Tenn. Church, Islamic Center Embrace Post 9/11, CBS News (Sept. 8, 2011, 12:41 PM), https://www.cbsnews.com/news/tenn-church-islamic-centerembrace-post-9-11/ [https://perma.cc/RRY2-MGAL].

7. Id. 
bullets. ${ }^{8}$ On September 15, a man who had been reported by an Applebee's waiter as saying that he wanted to "shoot some rag heads" shot a Chevron gas station owner Balbir Singh Sodhi, a Sikh-American. ${ }^{9}$ The man, Frank Roque, shot through his car window, and five bullets hit Sodhi, killing him instantly. Roque drove to a home he previously owned and had sold to an Afghan-American couple and fired on it. He then shot a Lebanese-American man. According to a police report, Roque said in reference to the 9/11 tragedy, "I [cannot] take this anymore. They killed my brothers and sisters." 10

\section{Community Relations Service Response to Post 9/11 Unfounded Racially Motivated Violence}

Due to CRS's unique jurisdiction to resolve community tensions relating to discriminatory practices based on race, color, or national origin, CRS was one of the few federal government agencies in the immediate aftermath of 9/11 reaching out to the nation's Arab, Muslim, and Sikh communities. ${ }^{11}$ As Rivera described in an interview in October 2001, "As quickly as [the attack] was linked to Middle Eastern terrorists, we wanted to avoid creating a tremendous backlash against other people who were Middle Eastern or appeared to be Middle Eastern, which included South-Asian and Sikh populations."12 From 2001 to 2016, CRS addressed a growing number of incidents in first responder fashion, provided preventative measures to reduce hate crimes, and undertook national initiatives to better confront these issues. ${ }^{13}$

CRS quickly mobilized following the terrorist attacks to assess community racial and ethnic tensions in areas of the country with high concentrations of Arab, Muslim, and South Asian populations. ${ }^{14}$ CRS

\section{Id.}

9. Valarie Kaur, His Brother Was Murdered for Wearing a Turban After 9/11. 15 Years Later, He Spoke to the Killer, PRI (Sept. 23, 2016, 12:00 PM), https://www.pri .org/stories/2016-09-23/his-brother-was-murdered-wearing-turban-after-911-lastweek-he-spoke-killer [https://perma.cc/7Z4L-PGVW].

10. Simran Jeet Singh, A Unique Perspective on Hate-Crimes: The Story of a Convicted Killer, HuffPost (July 20, 2012, 1:36 PM), https://www.huffingtonpost.com/ simran-jeet-singh/a-unique-perspective-on-hate-crimes-the-story-of-a-convicted-killer _b_1685020.html [https://perma.cc/H533-VC5D].

11. Working with Muslim, Arab, Sikh, South Asian, and Hindu Communities, U.S. Dep't Just. Community Rel. Serv., https://www.justice.gov/crs/page/file/1017261/ download [https://perma.cc/7E5S-AB65] (last visited Oct. 5, 2018).

12. Renaldo Rivera Interview, C.R. Mediation (Oct. 29, 2001), http://www.civil rightsmediation.org/interviews/Renaldo_Rivera.shtml [https://perma.cc/KQ87-UR $\mathrm{X} 6]$.

13. See Community Relations Service FY 2017 Performance Budget Congressional Submission, U.S. DeP'T Just., https://www.justice.gov/jmd/file/821066/download [https://perma.cc/NX7N-H6Q5] (last visited Oct. 5, 2018).

14. U.S. Dep't of Justice, Community Relations Service Fy 2001 Annual REPORT 7, https://www.justice.gov/archive/crs/pubs/fy2001/finalreport8_30.pdf [https:/ /perma.cc/74K4-7TQ6]. 
deployed staff members to sites where violence had or would most likely occur. On September 12, CRS directed staff in every office to identify cities with major concentrations of individuals of Middle Eastern or South Asian descent or of Muslim faith. ${ }^{15}$ CRS contacted local police personnel, city and state officials, and educators. They also reached out to Muslim and Arab-American civil rights leaders and other supporters. ${ }^{16}$ In New York, Rivera and his team worked with state officials, police departments, and state troopers to urge Americans to restrain any urge to act in a retaliatory way against other community members. ${ }^{17}$ As Rivera later recalled, CRS conciliators "encouraged that messaging to go into part of what Governor Pataki and Mayor Giuliani were saying in New York, that is, while the primary emphasis was on the rescue and the recovery, CRS encouraged messages around maintaining this moderation, restraint, tolerance, and vigorous law enforcement of hate crimes." 18

Rivera noted, however, that while officials wholly agreed with the need to urge restraint of any retaliatory urges, "[t]he question was how much air time they could give that particular message in the context of the immediate recovery effort." ${ }^{19}$ In the days immediately after the tragedy, the tolerance messaging was sometimes "left on the floor of the editing room." ${ }^{20}$ Still, there were hopeful signs for protecting vulnerable communities in the wake of the tragedy. In New York, the police department supported the prevention of misplaced retaliatory violence by securing Arab-Muslim neighborhoods along Atlantic Avenue in Brooklyn as well as the Islamic Cultural Center and Islamic schools in Bay Ridge. ${ }^{21}$

President George W. Bush crucially and memorably fashioned a statement that not only affirmed the nation's intent to hold the attackers responsible but also sought to discourage unfounded backlash against people of Muslim faith. In his September 20th address to the Joint Session of the 107th Congress, the President stated:

I also want to speak tonight directly to Muslims throughout the world. We respect your faith. [It is] practiced freely by many millions of Americans, and by millions more in countries that America counts as friends. Its teachings are good and peaceful, and those who commit evil in the name of Allah, blaspheme the name of Allah. The terrorists are traitors to their own faith, trying, in effect, to hijack Islam itself. The enemy of America is not our many Muslim

15. Id. at 11 .

16. Id. at 7.

17. Renaldo Rivera Interview, supra note 12.

18. Id.

19. Id.

20. Id.

21. Id. 
friends; it is not our many Arab friends. Our enemy is a radical network of terrorists, and every government that supports them. ${ }^{22}$

Attorney General John Ashcroft expressed a similar message. He warned, "We must not descend to the level of those who perpetrated Tuesday's violence by targeting individuals based on their race, their religion, or their national origin. Such reports of violence and threats are in direct opposition to the very principles and laws of the United States and will not be tolerated." 23

To support this message of unity and tolerance, Rivera worked with the New Jersey State Attorney General, the League of Municipalities, and the Association of Chiefs of Police in New Jersey to co-sponsor a series of three seminars on best practices and building bridges for police-community relations in the wake of the tragedy. ${ }^{24}$ The goal of the seminars was to reinforce the President, FBI, and Attorney General's message of restraint from committing hate crimes and vigorous law enforcement of hate crimes, and to encourage more CRS involvement in the rescue-and-recover effort, described further on in this chapter. ${ }^{25}$

CRS conciliators in New York and New Jersey (and throughout the country) had already established relationships with local Arab, Muslim, and South Asian groups that could be leveraged in CRS's hatecrime prevention efforts. ${ }^{26}$ Given his limited CRS staff of two permanent conciliators, it was critical for Rivera to also work in coordination with the following government workers: (1) federal partners like the U.S. Attorney's Office and FBI; (2) state partners like the state attorney generals, public safety offices, and their civil rights division; and (3) local partners like chiefs of police and municipal officials. Throughout this network, the goal was to deliver consistent messaging on tolerance; community protection; and the vigorous monitoring, investigation, and prosecution of hate crimes.

The stress on New Jersey communities was magnified by terrorism investigations in Paterson and Jersey City where some related terrorist activities were known to have taken place in $1993 .{ }^{27}$ Rivera recalled,

22. Charles Fried, Remembering 9/11, Harvard L. Today (Jan. 6, 2016), https:// today.law.harvard.edu/remembering-911/ [https://perma.cc/ZQ9E-JMMA].

23. U.S. Dep't of Justice, Confronting Discrimination in the Post-9/11 Era: Challenges and Opportunities Ten Years Later 5 (2011), https://www .justice.gov/sites/default/files/crt/legacy/2012/04/16/post911summit_report_2012-04.pdf [https://perma.cc/6QSJ-2R27]. However, over time, the Bush Administration did run programs that targeted Muslims, such as the Special Registration Program overseen by Ashcroft, which began in June 2002 and required Muslim men from specific countries to join a federal register and submit to fingerprinting.

24. Renaldo Rivera Interview, supra note 12.

25. Id.

26. See Working with Muslim, Arab, Sikh, South Asian, and Hindu Communities, supra note 11.

27. See e.g. Laura Lambert, World Trade Center Bombing of 1993, ENCYCLOPEDIA BRITANNICA, https://www.britannica.com/event/World-Trade-Center-bombing-of1993 [https://perma.cc/Q8YG-WUJK] (last visited Oct. 4, 2018) (recounting the inves- 
"[t]here was a larger premium by the investigative efforts on the Arab-Muslim and South-Asian communities [in New Jersey] than elsewhere in the country initially." 28 People in these communities become understandably fearful of being detained or arrested, jailed without due process, and eventually deported. CRS's goals centered on "developing relationships with institutional partners so that we [could] do two things: reduce the level of community tension, preventing its escalation, and maintain community stability."29

Critically, CRS's efforts in the New York area and throughout the country did not divert law enforcement and other governmental resources away from recovery and investigatory efforts. Because CRS has a distinctive mandate and plays the specific function of reducing tension, it complements law enforcement by keeping peace in communities during chaotic and anxious times. This parallel approach also enabled a constructive avenue for dialogue between community interests and federal law enforcement. New York City region CRS conciliators worked with Muslims and South Asians in cooperation with the Immigration and Naturalization Service ("INS") and the New York Immigration Service. Rivera recalled:

In our outreach to INS we introduced that there were some individuals who might be victims of hate crimes and have concerns around civil rights and civil liberties in addition to immigration questions. When we framed it with INS we talked to the larger sets of concerns that the community would have and then instead of it simply being a meeting around an individual's concern with INS we were able to raise them as larger questions and respond to them as federal partners. This permitted INS to show that it really did have more leniency in its policy and program work and also provided the community leadership groups with the reassurances they needed that their other concerns around civil rights as well as hate crimes were going to be addressed by INS and the Department of Justice. ${ }^{30}$

The recent technological shifts of the era enhanced CRS's communication efforts. Although telephone landlines were down in the New York City area for several weeks after the tragedy, the new phenomenon of widespread usage and availability of cell phones allowed CRS to work in ways it previously could not, accessing individuals at a faster pace and while displaced or in transit. ${ }^{31}$ Combining these new

tigation of Mohammad Salameh in Jersey City, NJ, in connection with the 1993 World Trade Center terrorist attack); David Kocieniewski, A Nation Challenged: The Holy Land Foundation; Paterson Again Finds Itself With Links to Sept. 11, N.Y. TIMES (Dec. 7, 2001), https://www.nytimes.com/2001/12/07/nyregion/nation-challenged-holyland-foundation-paterson-again-finds-itself-with-links.html [https://perma.cc/F6LNCQPJ] (last visited Oct. 4, 2018) (discussing FBI investigations into terrorist activities of the Holy Land Foundation based in Paterson, NJ, dating back to 1993).

28. Renaldo Rivera Interview, supra note 12.

29. Id.

30. $I d$.

31. Id. 
abilities with the agency's long-standing and trustful relationships with community-based organizations and advocacy groups allowed CRS to play a facilitating role between the New York Police Department ("NYPD"), the FBI, and communities experiencing incidents and receiving complaints about law enforcement treatment or lack of hate crime enforcement.

Because CRS does not have an investigative mandate, it is able to gain trust in communities that are otherwise reluctant to engage with state and federal authorities. ${ }^{32}$ Deep mistrust hampered relationships between New York law enforcement and communities racially profiled as potential terrorists. ${ }^{33}$ CRS conciliators' ongoing relationships with both these communities and the law enforcement agencies put them in a position to clarify miscommunications, convene with both sides peacefully, and broker agreements. For example, organizations such as the Arab American Institute and the National Merchants Association heard complaints about law enforcement profiling and harassing individuals or failing to follow up on alleged hate crime incidents. ${ }^{34}$ In Paterson and Jersey City, CRS conciliators brought together clerics, the mayor, the chief of police, and the city council to develop a strategy for reducing tension through a series of community meetings. ${ }^{35}$ Positive dialogue resulted in the deployment of handpicked officers who were inclined to a community policing approach to work with Muslim and other minority communities. CRS also provided a brief training for law enforcement on handling community tensions and responses in the World Trade Center disaster effort. ${ }^{36}$

As part of its commitment to reducing tensions and facilitating communication, CRS also took on a first responder role. ${ }^{37}$ Throughout its history, CRS has worked in disasters where community conflict exists not only when individuals are targeted for violence because of their race, but also when racial tensions exist with respect to a lack of adequate support. ${ }^{38}$ In response to these post-9/11 issues, CRS helped those affected by the tragedy access needed services. ${ }^{39}$ For example, the proximity of New York City's Chinatown to Ground Zero made Chinatown inaccessible to trucks for an extended period of time. Police barricades for rescue and recovery efforts further isolated the community. During the recovery period, the merchants in the area,

32. See id.

33. See id.

34. Arab Am. Inst. Found., Underreported Under Threat: Hate Crime in the United States and the Targeting of Arab Americans 33-34 (2018).

35. U.S. DeP't of Justice, supra note 14 , at 27-28.

36. Id. at 10.

37. Id. at 30.

38. See What We Do, U.S. DeP't of Justice (Feb. 14, 2017), https://www.justice .gov/crs/what-we-do [https://perma.cc/3JRG-QUMX].

39. U.S. Dep't of Justice, Community Relations Service FY 2002 Annual REPORT 30, https://www.justice.gov/archive/crs/pubs/fy2002/annualreport2002.pdf [https://perma.cc/FTV8-66ZX]. 
who comprised $95 \%$ of Chinatown business, were experiencing a $70 \%$ revenue loss. ${ }^{40}$ As a result, many businesses were being forced to close. ${ }^{41}$

CRS conciliators worked with merchants and other community leaders to alleviate some of the initial concerns regarding lack of phone communication, lack of road access into Chinatown, and loss of business. In concert with the Federal Emergency Management Agency ("FEMA"), CRS helped to provide technical assistance and consultation services in Chinatown by connecting those in need with organizations that could provide them services. Part of this assistance involved bringing in CRS conciliator Ben Lieu, who was then working out of CRS's Philadelphia office and could provide access to nearby resource networks. ${ }^{42}$

New York's Chinatown also served as a hub for distributing products to Asian groceries in cities along the East Coast. ${ }^{43}$ Conciliator Lieu worked with Verizon to bring in a truck with working phone lines so that Chinatown businesses could communicate with their East Coast customers. ${ }^{44}$ Rivera recalled that they worked alongside "NYPD in Manhattan South and also their emergency command center to allow some access for vehicles for food distribution businesses and others during certain hours of the day. [That is] something CRS can do, but FEMA cannot. [It is] just not part of their mission." ${ }^{45}$ CRS also helped convene town meetings with FEMA and the Small Business Administration for financial support. ${ }^{46}$ This example illustrates how CRS can play a problem-solving role that is outside the purview of other federal agencies, utilizing knowledge of how to navigate (1) federal and other governmental bureaucracies, (2) cultural competency, (3) relationships with specific communities, and (4) the ability to convene stakeholder experience, expertise, and resources.

Beyond Chinatown, community conflict, based on race, color, and national origin, over access to recovery services was a major concern, especially for low-income areas with a significant concentration of minorities and recent immigrants, some of which had limited English

40. Jennifer S. Lee, A Nation Challenged: The Economy; Battered by Sept. 11, Chinatown Economy Remains Crippled, N.Y. TIMEs (Nov. 21, 2001), https://www.nytimes .com/2001/11/21/nyregion/nation-challenged-economy-battered-sept-11-chinatowneconomy-remains-crippled.html [https://perma.cc/8B84-6BMM].

41. See Barbar Ross, Chinatown's Garment Biz Shrivels, Tourist Traffic Dwindles in Lasting Blow of 9/11, DAILy News (Sept. 5, 2011, 4:00 AM), http://www.nydaily news.com/new-york/chinatown-garment-biz-shrivels-tourist-traffic-dwindles-lastingblow-9-11-article-1.954982 [https://perma.cc/4WLP-V3E9].

42. Interview with Ben Lieu, CRS Conciliator, U.S. Dep't of Justice Cmty. Relations Serv.

43. Id.

44. Id.

45. Renaldo Rivera Interview, supra note 12.

46. Id. 
proficiency. ${ }^{47}$ This dynamic is often seen in large-scale disasters. ${ }^{48}$ Those with resources, networks, English fluency, and knowledge of how to access the support system can more readily get their needs met than those who do not. Conflicts arise particularly when local leaders and representatives advocate for their communities and criticize politicians and agencies for not doing enough. Early on after the 9/11 attacks, CRS worked with the New York Community Trust and the United Way of New York, which set up the September 11 Fund. ${ }^{49}$ The fund sought to meet the immediate and long-term needs of 9/11 victims, families, and communities affected by the terrorist attacks. ${ }^{50}$ Its grants addressed needs such as cash assistance, employment assistance, health care, and mental health services. ${ }^{51}$

Prior to CRS's involvement, these organizations decided to use Safe Horizons, which at the time was the largest victim-services organization in the country, to provide social services for victims of abuse and violent crime in fifty-seven locations throughout the five boroughs of New York City. Numerous local, state, and federal agencies provided relief services through Safe Horizons and other community and faithbased organizations. These organizations provided relief services following the attack regardless of immigration status, which was critical because most governmental assistance required citizenship or legal immigrant status. ${ }^{52}$ Rivera further noted that "individuals, between language difficulty and immigration questions, even if they are legally here, have not always been able to get what they need from FEMA." ${ }^{53}$ CRS coordinated and facilitated a significant amount of media attention related to accessing these services. "That was an important entree for people across the board," Rivera noted, "particularly in the lower income areas in New York, and those who might have immigration status questions, to ... get some relief." 54

\section{Community Relations Service Work Across THE COUnTRY}

CRS's activities were not limited to the New York area. ${ }^{55}$ In addition to conducting outreach throughout the country immediately after the tragedy, CRS senior leaders, who were led by Director Sharee Freeman, met with leaders of the national Arab-American, Muslim,

47. Id.

48. $I d$.

49. Id.

50. Kenneth R. Feinberg, U.S. Dep't of Justice, Final Report of the Special Master for the September 11th Victim Compensation Fund of 20013 (2004).

51. Id. at 6-7, 37.

52. See Renaldo Rivera Interview, supra note 12.

53. $I d$.

54. Id.

55. U.S. Dep't of Justice, supra note 14, at 11, 43. 
and Sikh communities from September to November of 2001. These meetings guided CRS's conflict resolution and violence prevention services following real and potential backlash against these communities. ${ }^{56}$ Specifically, in the months following September 11, under Freeman's leadership, CRS conducted six main activities to prevent violence and reduce tension. ${ }^{57}$ These included: (1) conducting hate crimes training for police departments and school administrators with major Muslim and Arab-American populations; (2) helping and encouraging state attorneys general and U.S. Attorneys to establish working groups to focus on September 11 backlash issues; (3) encouraging municipalities, police departments, schools, colleges, and universities with major Muslim and Arab-American populations to plan racial dialogues; (4) assisting local human rights commissions and similar organizations to develop work plans that focused on outreach to Arab-American and Muslim communities and strategies to bring about better relations between these communities and the broader community; and (5) convening the leading school superintendents and principals to discuss best practices to address backlash issues affecting Muslim and Arab American students in their schools. ${ }^{58}$

CRS conciliators worked not only with Arab and Muslim communities but also with South-Asian and particularly Sikh communities, who have origins in India. ${ }^{59}$ Although the Sikh religion is not affiliated with Islam, the visually distinct cultural practices of observant Sikhsespecially the men, who wear turbans and display full facial hairhave attracted attention from people attempting to target Muslims. ${ }^{60}$ While anti-Middle Eastern prejudice and discrimination in the United States predates 2001 and had previous spikes (like the Iran hostage crisis), the shock, horror, and tragedy of September 11 was unprecedented. For Arab, Muslim, South-Asian, Sikh, and other residents whose appearances could resemble Middle Eastern characteristics, the fear of prejudice, discrimination, and even violent hate crime increased exponentially.

\section{Community Relations Service Work in OAK Creek Gurdwara Tragedy}

These issues have not been quick to resolve. Even more than a decade later, they continue to plague the nation. On August 5, 2012, six

56. Id. at 9 .

57. Id. at 7-12.

58. Id.

59. Id. at 3.

60. Steven Yaccino et al., Gunman Kills 6 at a Sikh Temple Near Milwaukee, N.Y. TIMES (Aug. 5, 2012), https://www.nytimes.com/2012/08/06/us/shooting-reported-attemple-in-wisconsin.html [https://perma.cc/5FZD-QTVY]. 
worshippers at a gurdwara in Oak Creek, Wisconsin, were shot and killed by a white extremist. ${ }^{61}$

Within hours of the shootings, CRS was in contact with national and local Sikh officials, the U.S. Attorney for the district, and numerous federal and local law enforcement officials. ${ }^{62}$ The next day, CRS senior leadership and White House staff participated in a conference call with more than eighty community-based organizations, as well as Incident Community Coordination Team conference calls convened by the Department of Homeland Security. ${ }^{63}$ The objective of these calls was to provide timely assistance and support as well as solicit feedback from community leaders. ${ }^{64}$ On the same day, in response to a reporter's question, President Obama stated:

If it turns out, as some early reports indicate, that it may have been motivated in some way by the ethnicity of those who were attending the temple, I think the American people immediately recoil against those kinds of attitudes, and I think it will be very important for us to reaffirm once again that, in this country, regardless of what we look like, where we come from, who we worship, we are all one people, and we look after one another and we respect one another. ${ }^{65}$

CRS and James Santelle, the U.S. Attorney for the Eastern District of Wisconsin, organized a key leadership meeting to discuss hate crimes, analyze community concerns over the shooting, coordinate law enforcement, and assess the community's needs for funerals. ${ }^{66}$ CRS, along with federal and local partners, planned and moderated a community meeting at Oak Creek High School, attended by more than 250 people. ${ }^{67}$ As one of the members of the local Sikh community noted, they experienced "soft attacks" like being told to leave the country and other verbal insults. The member noted that the massacre

61. Id.; Esha Sarai, 5 Years After Massacre, Wisconsin Sikhs Continue Outreach, Service, Voice Am. (Aug. 5, 2017), https://www.voanews.com/a/wisconsin-sikh-massa cre-anniversary/3973627.html [https://perma.cc/2GDH-Y8CJ].

62. Grande Lum, DOJ's Community Relations Service Delivers Mediation and Conciliation Services to AAPI Community, Овамa White House (Dec. 7, 2012), https://obamawhitehouse.archives.gov/blog/2012/12/07/dojs-community-relations-ser vice-delivers-mediation-and-conciliation-services-aapi-c [https://perma.cc/6P3W-JD $\mathrm{SF}$.

63. Grande Lum et al., The United States Department of Justice Community Relations Service: Assisting Communities in Restoring Conflicts and Restoring Peace, PoLiCe Chief Mag., Dec. 2013.

64. Gautam Raghavan \& Paul Monteiro, Honoring the Victims of the Oak Creek Tragedy, Овама White House (Aug. 14, 2012), https://obamawhitehouse.archives .gov/blog/2012/08/14/honoring-victims-oak-creek-tragedy [https://perma.cc/2KHX-DS UZ].

65. Id.

66. Lum, supra note 62.

67. U.S. Dept. Just., Community Relations Service FY 2012 Annual RePORT v, https://www.justice.gov/sites/default/files/crs/legacy/2013/07/22/crs-fy2012-an nual-report.pdf [https://perma.cc/AC7H-NQL9]. 
heightened tension and fear: "This was a heart attack. This was a cardiac arrest. This was a watershed moment for our culture."68

CRS participated in numerous national and community calls totaling over 200 participants to identify resources, provide technical assistance, and address concerns following the shooting. ${ }^{69}$ CRS conciliators also reached out to Sikh and Muslim leaders throughout the country due to concerns over possible copycat crimes and safety at their houses of worship. ${ }^{70}$ Throughout the country, conciliators began convening meetings and providing cultural competency trainings. On August 10, Attorney General Eric Holder delivered a speech honoring the victims and families affected by the tragedy. ${ }^{71}$ Holder acknowledged the reality of racially profiled hate crimes and pledged action: "Unfortunately, for the Sikh community, this sort of violence has become all too common in recent years ... This is wrong. It is unacceptable. And it will not be tolerated." 72

Given CRS's expertise in Sikh culture and its relationships with Sikh organizational leadership throughout the country, CRS Regional Director Harpreet Mokha Singh and I met with First Lady Michelle Obama's team to prepare for her visit to Oak Creek. On August 23, Obama privately visited with victims and families to offer her support and condolences. ${ }^{73}$ Before a meeting in the Oak Creek High School, she told temple Secretary Kulwant Dhaliwal and Oak Creek Mayor Stephen Scaffidi, "I am anxious to meet with the families and lend whatever support I can." 74

CRS stayed involved in the Oak Creek community, conducting a follow-up conference six months later. ${ }^{75}$ Local community members; U.S. Attorney Santelle; Oak Creek's mayor, police chief, and school superintendent; and representatives of the FBI, the Bureau of Alcohol, Tobacco, Firearms and Explosives, and the Milwaukee County

68. Meg Jones \& Annysa Johnson, Temple Cleaned, Forum Held: Conditions of Two Injured Upgraded, Milwaukee J. Sentinel, Aug. 10, 2012, at B1.

69. Grande Lum, DOJ's Community Relations Service Delivers Mediation and Conciliation Services to AAPI Community, Oвамa White House Blog (Dec. 7, 2012, 3:52 PM), https://obamawhitehouse.archives.gov/blog/2012/12/07/dojs-communi ty-relations-service-delivers-mediation-and-conciliation-services-aapi-c [https://perma .cc/795Q-3WE2].

70. $I d$.

71. Id.

72. Eric Holder, Attorney General Speaks at the Oak Creek Memorial Service U.S. DEPT. Just. (Aug. 10, 2012), https://www.justice.gov/opa/speech/attorney-generaleric-holder-speaks-oak-creek-memorial-service [https://perma.cc/5TMU-RSSA].

73. Annysa Johnson, Michelle Obama Meets with Sikh Shooting Victims, Families, MilwaukeE J. Sentinel (Aug. 23, 2012), http://archive.jsonline.com/news/religion/mi chelle-obama-meets-with-sikh-shooting-victims-families-n46je7q-167234425.html/

[https://perma.cc/F3NR-2LCF].

74. Id.

75. Sikh Coalition Attends Six-Month Follow-Up Conference in Oak Creek, SIKH CoAlition (Feb. 4, 2013), https://www.sikhcoalition.org/blog/2013/sikh-coalition-at tends-six-month-follow-up-conference-in-oak-creek/ [https://perma.cc/RY7Y-CQ6W]. 
District Attorney's Office attended the conference. ${ }^{76}$ The attendees discussed: (1) government funding used to increase Oak Creek Gurdwara security measures; (2) Justice Department victim compensation funding that distributed medical and other compensation to tragedy victims; and (3) previous Sikh cultural awareness training in Oak Creek. The Oak Creek police chief noted at the event, "It is not their temple. It is now our temple."77

CRS took a leading role responding to the Oak Creek tragedy, along with the Department of Justice's Civil Right Division, by working with the FBI to add anti-Sikh, anti-Hindu, and anti-Arab categories to the Uniform Crime Reporting ("UCR") program's hate crime data collection. ${ }^{78}$ Law enforcement workers use this form to track hate crimes throughout the country. ${ }^{79}$ Without a specific anti-Sikh category, it was not possible to disaggregate hate crimes data to determine how many incidents targeted Sikhs rather than Muslims, so it was difficult to determine the problem's extent or trends. ${ }^{80}$ Hate crimes - which often succeed in their intimidating and terrifying communities in which people look, speak, or worship like the crime's individual victims - can worsen tensions and embolden copycat attempts, particularly if the intent is unrecognized. Because law enforcement reporting is voluntary, hate crimes are tremendously underreported in the United States. Specific categories like Sikh and Arab increases trending data on hate crimes targets.

Under my leadership in September 2012, CRS launched a newly revised Sikh cultural awareness training program to inform and educate communities experiencing tension, serve as a resource to prevent hate crimes, and train people to assist their communities in preventing and responding to hate crimes against Sikhs. ${ }^{81}$ At that event, Deputy Attorney General James Cole announced that the Justice Department supported the addition of these newest categories. ${ }^{82}$ Shortly thereafter, the United States Senate Subcommittee on the Constitution, Civil

76. Id.

77. $I d$.

78. See Azmi Haroun, Racialized as White, Treated Otherwise: How Anti-Arab Hate Becomes Invisible in The U.S., New ArAB (Oct. 11, 2018), https://www.alaraby .co.uk/english/comment/2018/10/11/how-anti-arab-hate-becomes-invisible-in-the-us [https://perma.cc/K4EX-QLC2].

79. About UCR, Fed. Bureau Investigation, https://ucr.fbi.gov/hate-crime/ 2015/resource-pages/aboutucrmain_final [https://perma.cc/C82U-3RXU] (last visited Oct. 4, 2018).

80. See Ronald L. Davis \& Patrice O'Neill, How Low Hate Crime Numbers Keep Tensions High, Not In Our Town (June 6, 2016, 2:13 PM), https://www.niot.org/ cops/resources/article-how-low-hate-crime-numbers-keep-tensions-high [https://per ma.cc/6PZF-SNGL].

81. U.S. DePt. Just., supra note 67, at 7-8.

82. James Cole, Deputy Attorney James M. Cole Speaks at the Community Relations Service Sikh Cultural Competency Training Preview U.S. DePT. Just. (Sept. 19, 2012), https://www.justice.gov/opa/speech/deputy-attorney-general-james-m-colespeaks-community-relations-service-sikh-cultural [https://perma.cc/3RSC-5JZC]. 
Rights, and Human Rights heard the testimony of Harpreet Singh Saini on behalf of the children who lost parents or grandparents during the massacre in Oak Creek. ${ }^{83}$ Saini further emphasized the importance of the categories: "The FBI does not track hate crimes against Sikhs. My mother and those shot that day will not even count on a federal form. We cannot solve a problem we refuse to recognize." 84

The Civil Rights Division and CRS hosted a community roundtable meeting to discuss the issue with representatives from various religious and interfaith organizations. ${ }^{85}$ The attending groups strongly supported adding anti-Sikh and anti-Hindu categories to the hate crime data. ${ }^{86}$ The desire for adding an anti-Arab bias under either the race or ethnicity categories was also suggested. ${ }^{87}$

On August 18,2013, in one of his final acts before leaving the office, FBI Director Robert Mueller included this statistical reporting in the Bureau's UCR program. ${ }^{88}$ The final categories to be included were hate crime offenses committed against Sikh, Hindu, Arab, Buddhist, Mormon, Jehovah's Witness, and Orthodox Christian individuals. ${ }^{89}$ The FBI worked with Hate Crime Coalition members to develop new definitions and training scenarios based on the new religion and Arab bias motivations. ${ }^{90}$ Collecting the new religion and Arab bias motivation categories began on January 1, 2015, and have been reported in the annual Hate Crime Statistics reports ever since. ${ }^{91}$

\section{The Work Goes ON}

Former Transportation Secretary Norman Mineta said, reflecting ten years later on the hate crimes that followed the attack on the World Trade Center, "The tragedy of September 11th should be remembered in the sense of making sure that we [do not] let our emotions run away in terms of trying to show our commitment and convic-

83. Hate Crimes and the Threat of Domestic Terrorism: Hearing Before the Subcomm. on the Constitution, Civil Rights \& Human Rights of the Comm. on the Judiciary, 112th Cong. 62-64 (2012) (statement of Harpreet Singh Saini, Oak Creek, Wis.).

84. Id. at 64 .

85. Town Hall Meeting of Religious Organizations at Dept. of Justice Addresses Religion-Based Hate Crimes, U.S. DeP'T. Just. (Nov. 2012), https://www.justice.gov/ crt/town-hall-meeting-religious-organizations-department-justice-addresses-religionbased-hate\#1 [https://perma.cc/BLD9-SF4C].

86. Id.

87. Id.

88. Id.

89. See Crimes Against Minorities to be Considered Hate Crimes in US, FIRstPost (Aug. 3, 2013 11:42 AM), https://www.firstpost.com/world/crimes-against-minoritiesto-be-considered-hate-crimes-in-us-1007391.html [https://perma.cc/5QSA-9LUM].

90. Anthony H. Cordesman, Terrorism and Hate Crimes: Dealing with All of the Threats from Extremism, CTR. FOR STRATEGIC \& INT'L STUd. (July 5, 2017), https:// www.csis.org/analysis/terrorism-and-hate-crimes-dealing-all-threats-extremism [https:/ /perma.cc/YB53-QSYC].

91. See Haroun, supra note 78. 
tion about patriotism [and] loyalty." 92 The events created a new chapter in American race relations, one in which racial tensions and fear were higher than ever for Arabs, Muslims, South Asians, Sikhs, and others who could be targeted in anti-Islamic hysteria because of their physical appearance or dress. In 2011, a CBS-New York Times poll found that $78 \%$ agreed that Muslims, Arab-Americans, and immigrants from the Middle East are singled out unfairly by people in this country.$^{93}$ Shortly after the September 11 attacks, this number stood at $90 \% .{ }^{94}$ The same poll also found that one in three Americans think Muslim-Americans are more sympathetic to terrorists than other Americans. ${ }^{95}$

To address these misconceptions in the years following 9/11, CRS has done a significant amount of outreach, dispute resolution, and training to mitigate unfounded backlash against Arabs, Muslims, and Sikhs. ${ }^{96}$ Under CRS Director Freeman, the agency produced Sikh and Muslim cultural-competency trainings and two training videos: $O n$ Common Ground, which provides background on Sikhism and concerns about safety held by Sikhs in America; and The First Three to Five Seconds, which provides background on Muslims and information on their interactions with law enforcement. ${ }^{97}$

In 2009, President Obamas signed the Matthew Shepard-James Byrd Junior Hate Crimes Prevention Act. The Act explicitly gave CRS jurisdiction to respond to and prevent hate crimes. For the first time, CRS jurisdiction expanded beyond race. Specifically, CRS was now authorized to work on issues of religion, gender, sexual orientation, gender identity, and disability in addition to race, color, and national origin. When I became CRS Director in 2012, following the continued incidents of unfounded violence and prejudice against those perceived as sharing heritage with Middle Eastern terrorists, I directed the agency to update the trainings and launched an initiative

92. Jennie L. Ilustre, Mineta Urges Vigilance vs. Post-9-11 Racial Profiling, AsIan FORTUNE, http://www.asianfortunenews.com/site/article_0911.php?article_id=24 [https://perma.cc/N7Z9-SL8M] (last visited Oct. 11, 2018).

93. Brian Montopoli, Poll: Most Say Muslims are Singled Out Unfairly, CBS News (Sept. 8, 2011, 8:44 AM), https://www.cbsnews.com/news/poll-most-say-muslims-aresingled-out-unfairly/ [https://perma.cc/8MTS-UU5Y].

94. Id.

95. Stephanie Condon, Poll: 1 in 3 Think Muslim Americans More Sympathetic to Terrorists than Other Americans, CBS News (Sept. 9, 2011), https://www.cbsnews .com/news/poll-1-in-3-think-muslim-americans-more-sympathetic-to-terrorists-thanother-americans/ [https://perma.cc/N8W7-4V8L].

96. See Working with Muslim, Arab, Sikh, South Asian, and Hindu Communities, supra note 11.

97. See Sikh Cultural Awareness Training Video Now on Justice Department Web Site, Sikh Am. Legal Def. \& Educ. Fund (Feb. 5, 2008), http://saldef.org/news/sikhcultural-awareness-training-video-now-on-justice-department-web-site/\#.W7eEVWh Kjic [https://perma.cc/K9JD-A8KD]; see generally The First Three to Five Seconds: Understanding Arab and Muslim Americans, U.S. DeP'T Just., https://www.justice .gov/crs/intro [https://perma.cc/9BKL-7VLX]. 
for regional offices to conduct these Sikh and Muslim cultural-competency trainings. In the years following $9 / 11$, controversy has continued over racial profiling of Arab, Muslim, and Sikh individuals. Owing to the nature of the attack, one particular area of ongoing concern is access to airplane flights. Director of Transportation Mineta recalled how the racial profiling he witnessed echoed his own experience as a Japanese-American citizen:

[T]here were a lot of people saying, "[We are] not [going to] let Middle Easterners or Muslims on the planes." And I thought about my own experience [during World War II] because people [could not] make the distinction between the people who were flying the airplanes that attacked Pearl Harbor and the people who were living in Washington, Oregon, and California, who looked like the people flying the airplanes. ${ }^{98}$

In response to this problem, CRS trained thousands of law enforcement and Transit Security Association employees on cultural professionalism in working with Arab, Muslim, and Sikh individuals. ${ }^{99}$ The work of addressing the profiling and mistreatment of Arab-Americans, Muslims, and Sikhs also spiked after the 2013 bombing of the Boston Marathon. CRS conciliators again reached out to leaders throughout the country at mosques and gurdwaras to confront safety and security issues regarding houses of worship and concerns about backlash violence based on faith, nationality, and race. ${ }^{100}$

Since 9/11, CRS's work on racial profiling continues to respond to increasing conflicts and tensions both within the United States and around the globe. In the wake of the 9/11 tragedy, CRS adjusted its priorities and reallocated resources in the wake of the September 11 tragedy to address the needs of targeted communities and further intercultural understanding. CRS did so by increasing the religious awareness training provided to law enforcement and other agencies, and it committed more resources to working with Muslim and Sikh faith and advocacy organizations and people. This work was not originally envisioned when the 1964 Civil Rights Act created CRS. However, this new focus reflects how the model of the African-American civil rights movement has inspired other efforts to attain equality and justice for minority groups in the United States.

Just as the tragedy in Selma helped lead to the passage of the 1965 Voting Rights Act, the Oak Creek tragedy helped lead the FBI to update its hate crime categories. Former FBI Director James Comey

98. Ilustre, supra note 92.

99. U.S. Dept. Just., Community Relations Service Annual Report Fy 2011 9, 21 (2011), https://www.justice.gov/sites/default/files/crs/legacy/2012/04/27/crsannual-report2012.pdf [https://perma.cc/PPW4-7L93].

100. U.S. Dept. Just., Community Relations Service Annual Report 20133 (2013), https://www.justice.gov/sites/default/files/pages/attachments/2014/08/20/2013_ annual_report.pdf [https://perma.cc/94UV-YSLM]. 
articulated this idea best in his speech to the Anti-Defamation League, stating "do a better job of tracking and reporting hate crime to fully understand what is happening in our communities and how to stop it." 101 The Community Relations Service has evolved over time since its 1964 origins, and a substantial component has been the work in response to post 9/11 unfounded racial and religious violence.

101. James B. Comey, The FBI and the ADL: Working Toward a World Without Hate Fed. Bureau Investigation (Apr. 28, 2014), https://www.fbi.gov/news/ speeches/the-fbi-and-the-adl-working-toward-a-world-without-hate [https://perma.cc/ 4RS2-HQEE]. 
